\title{
IMAN KATOLIK MEMANDANG BERBAGAI PRAKTIK TERAPI ALTERNATIF ${ }^{1}$
}

\author{
Cahyo Christanto
}

\begin{abstract}
:
There are various efforts to achieve a cure: the effort through prayer, through the efforts of conventional medicine and the effort through alternative therapies. The fact that sometimes happens is that the methods that work in synergy but often walk alone or even contradictory. For Catholics, this can make the faithful confused and wondering. It can also cause the pros and cons of them. This study aims to formulate the principles of assessment of alternative therapies, in the light of the Catholic faith, as well as offering pastoral steps on alternative therapies. For that, researcher first learns the concepts of healing in Scripture, learns and explores the ins and outs of alternative therapies in detail in the traditions and culture of the East, conducts a review of some alternative therapies with the help of theoretical Physics of Electricity, Epigenetics, Quantum Physics, and Brain Wave theory. To that end, researcher uses the means of interviews with some practitioners of alternative therapies and conducts the study of supportive literature. After reflecting theologically the concept and practice of alternative therapies in the light of the Catholic faith, this research proposes "the principles of assessment of the Church" on alternative therapies and pastoral steps. With the wise "principle of assessment", the Church can help the faithful to, with a clear conscience, take a critical attitude toward alternative therapies.
\end{abstract}

\section{Kata-kata Kunci:}

Terapi alternatif, umat beriman Katolik, prinsip-prinsip penilaian, quantum, energi, kesadaran, discernment.

\section{PENDAHULUAN}

\subsection{Latar Belakang Masalah}

Pada abad kedua puluh satu sekarang ini, penyakit dipahami dengan sangat berbeda dari pandangan manusia abad pertama. Kini kita hidup dalam suatu dunia pengetahuan medis yang tidak pernah dapat dibayangkan oleh manusia pada abad pertama. Kemajuan ilmu pengetahuan dan kedokteran Barat, atau disebut juga kedokteran konvensional, sepertinya telah membuat sakit-penyakit dapat dijelaskan tanpa harus dihubungkan dengan dosa dan hukuman Allah.

Jauh sebelum kedokteran Barat berkembang, dalam lingkup budaya Cina, India, dan Jepang, orang telah mengenali penyakit sebagai akibat ketidakseimbangan energi (Chi, Prana, Ki) tubuh dan energi alam semesta. Tai Chi, Yoga, Reiki, akupunktur, dan akupresur adalah cara-cara terapi lokal untuk menyelaraskan energi kehidupan yang berkembang sesuai dengan budaya dan alam pemikiran Timur. Tradisi Timur ini meyakini bahwa penyakit bisa disembuhkan jika sumbatan energi dalam tubuh sudah dinetralkan. Jenis-jenis terapi di atas sekarang ini justru mendapatkan sebutan sebagai terapi alternative, karena dianggap menjadi terapi di luar metode kedokteran Barat. Beberapa metode terapi alternatif ini banyak menggunakan filosofi Timur seperti energi, chi, prana, dan cakra. Menurut filosofi Timur, sakit atau gangguan kesehatan adalah terjadinya sumbatan atau ketidakharmonisan chi dalam tubuh orang yang sakit maupun ketidakharmonisan relasi chi dengan lingkungan sekitarnya. 
Konsep ini mungkin tampak mengadaada dan sulit dibuktikan. Dan tentu saja karena sulit dipahami orang awam, hal ini tidak mudah diterima, atau bahkan sangat tidak masuk akal. Menurut saya inilah keunggulan konsep dan filosofi Timur yang melihat bahwa "kesembuhan" dari penyakit itu tidak hanya menyembuhkan penyakitnya, tetapi sekaligus memulihkan "keutuhan" manusiawinya juga. Namun hal tersebut juga sekaligus menjadi kelemahannya karena sulit dibuktikan secara ilmiah.

\subsection{Rumusan Pertanyaan}

Kehadiran berbagai terapi yang menawarkan penyembuhan dan hidup sehat telah membuat umat beriman Katolik bingung dan bertanyatanya. Beberapa pertanyaan mereka, diantaranya, "Apakah orang Katolik boleh mendapatkan atau mendalami terapi alternatif?Bila ada keberatan, bagaimana cara membedakan terapi alternatif yang baik dan tidak? Bagaimana kita dapat mengatasi pengaruh terapi alternatif yang kurang baik? Terapi manakah yang sesuai dengan iman Katolik? Apakah Gereja hanya mendukung pengobatan konvensional saja?"

Beberapa pertanyaan itu menunjukkan beberapa indikasi bahwa (1) ada keragu-raguan umat dalam memandang terapi alternatif, (2) ada yang sudah mendalami karena merasakan manfaat yang nyata dalam hidupnya, (3) ada yang mantap menyatakan ketidaksetujuannya karena melihat bahwa terapi alternatif tidak sesuai dengan penghayatan iman Katolik, atau (4) ada yang dengan "diam-diam" menjadi praktisi salah satu terapi alternatif agar tidak menjadi batu sandungan bagi umat yang lain, (5) ada pro-kontra penilaian yang menjurus pada sikap saling menghakimi di antara umat beriman.

Melihat kenyataan ini Gereja Katolik di Indonesia perlu memberikan suara yang bijak agar umat beriman tidak bimbang. Beberapa metode terapi alternatif tampaknya menjanjikan pendekatan penyembuhan yang sangat efektif. Tetapi tampaknya kita perlu waspada. Kita tidak bisa begitu saja menelan semangat zaman ini dengan hanya menyetujui cara pendekatan yang disajikan oleh berbagai terapi alternatif ini.

\subsection{Tujuan Penulisan}

Tulisan ini berupaya memberikan pemahaman kepada umat beriman Katolik akan beragamnya metode terapi alternatif dalam kehidupan sehari-hari. Dengan tinjauan singkat seluk beluk terapi alternatif dalam tradisi dan budaya Timur pada umumnya, tinjauan sains dan kajian atas beberapa terapi alternatif dengan bantuan teori Fisika Listrik, Epigenetika, Fisika Quantum, dan teori Gelombang Otak, juga dalam terang iman Katolik, umat beriman diajak melihat, menilai, atau memilih terapi alternatif secara bijaksana.Umat dibantu dengan beberapa prinsip penilaian teologis atas terapi alternatif dan langkah-langkah pastoral yang mungkin dilakukan. Dengan demikian umat dibantu pula untuk melihat bahwa inilah kekayaan cara Allah terlibat dalam kehidupan manusia.

Bagi masyarakat, penelitian ini diharapkan membantu untuk memahami peristiwa "penyembuhan" yang terjadi dalam tradisi kedokteran Barat (konvensional) maupun dalam kedokteran non-konvensional. Dengan pemahaman yang jernih akan penyembuhan dengan bantuan penjelasan sains dan dengan banyak bukti lain yang mendukung diharapkan membantu masyarakat untuk sadar bahwa hidup sehat, tenang, damai, dan harmoni adalah pilihanpilihan yang mungkin diambil karena kita diundang untuk aktif terlibat dalam karya keselamatan Allah menciptakan kehidupan bersama yang damai.

\subsection{Metode Penulisan}

Penelitian ini menggunakan metode penelitian lapangan yaitu dengan melakukan wawancara kepada: lima orang kenalan praktisi prana, tiga orang praktisi reiki, dua orang praktisi yoga dan empat orang praktisi akupunktur dan akupressur (khususnya yang berdomisili di Yogyakarta) dan kepada dua puluh orang pasien yang disembuhkan dengan metode-metode ini. Wawancara dilakukan secara langsung maupun lewat korespondensi email dan jejaring sosial Facebook.

Untuk memperoleh informasi terperinci mengenai "penyembuhan" dari sudut pandang sains (Biologi dan Fisika) dan Teologi, penulis melakukan studi pustaka yang mendukung. Sebagai upaya untuk mempertemukan sains dan teologi, pengandaian dasar dari tulisan ini adalah adanya perjumpaan antara sains dan teologi. Dalam perspektif Kristiani, hanya ada satu sumber penyembuh yaitu Allah pencipta, maka semoga baik sains dan teologi berjalan bersama- 
sama mencoba memahami realitas penyembuhan ini sebagai realitas kehidupan.

\section{TERAPI ALTERNATIF: DEFINISI DAN METODE}

Istilah "terapi alternatif" sudah begitu populer, tetapi sampai saat ini definisi yang baku untuk istilah ini belum ada. Tidak heran jika pemahaman tentang terapi alternatif pun sangat beragam. Jika menelusuri arti kata terapi, dalam Merriam Webster Dictionary, kata 'terapi' berarti treatment especially of bodily, mental, or behavioral disorder. Sedangkan dalam Oxford Dictionary kata "terapi" berarti treatment intended to relieve or heal a disorder. Menurut Kamus Besar Bahasa Indonesia, definisi terapi adalah "usaha untuk memulihkan kesehatan orang yang sedang sakit". Dari tiga definisi di atas, tidak disebut 'usaha medis' dan juga tidak disebut usaha menyembuhkan penyakit. Definisi terapi lebih luas daripada sekadar pengobatan atau perawatan.

Kata "alternatif" dalam istilah "terapi alternatif" bisa dijelaskan sebagai pilihan, cara atau metode yang lain. Akan tetapi menurut Karen Lee Fontaine dan Bill Kaszubski ${ }^{2}$ kata "terapi alternatif" merupakan payung atau istilah umum untuk ratusan terapi dari seluruh dunia yaitu beragam terapi yang berkembang dalam kebudayaan-kebudayaan: penduduk asli Amerika, Mesir, Yunani, Cina, India, dan Asia, yang telah diwariskan selama ribuan tahun, baik secara lisan maupun tertulis.

Meskipun metode pendekatan terapi alternatif itu beragam, akan tetapi terapi-terapi tersebut memiliki kemiripan dalam hal prinsip. Prinsip itu adalah paradigma "keutuhan" manusia dan keyakinan bahwa manusia lebih dari fisiknya. Terapi alternatif memiliki prinsip bahwa tubuh, pikiran, dan jiwa adalah keutuhan. Karenanya, unsur mental, emosional, spiritual, dan sosial dianggap berperan penting dan setara dalam mendukung kesehatan. Beberapa prinsip umum yang lain adalah:

1. Setiap orang memiliki kemampuan untuk "menyembuhkan diri sendiri".

2. Setiap orang sepenuhnya bertanggung jawab atas kesehatannya sendiri.

3. Alam, waktu, dan kesabaran adalah penyembuh yang hebat.
Perawatan medis konvensional seringkali berfokus pada gejala fisik dalam upaya untuk menghilangkan penyakit dan gejala penyakitnya. Terapi alternatif melihat tidak hanya gejala fisik, tetapi juga pengalaman emosional dan mental, pada cara merasa dan berpikir tentang diri sendiri dan orang lain yang sangat memengaruhi kesehatan fisik. Jika aspek-aspek non fisik tidak dipertimbangkan, maka penyakit dan gejalanya hanya sebagian dapat diatasi, dengan sedikit jaminan bahwa penyakit ini tidak akan kembali.

Terapi alternatif melibatkan proses di mana kondisi tubuh, pikiran, dan jiwa yang terganggu dibawa menuju keadaan yang lebih sehat dan seimbang. Untuk mencapai hasil yang optimal dan tahan lama, terapi alternatif dilakukan pada semua tingkat yaitu fisik, emosi, psikologi, energi, dan spiritual. Terapi yang hanya meredakan gejala tanpa mengatasi penyebabnya akan mendatangkan masalah kembali. Terapi alternatif menyentuh semua tingkat, baik gejala maupun penyebab sakit-penyakitnya. Dengan demikian, terapi itu sendiri diharap bersifat efektif, komprehensif, dan menyeluruh (holistic) ${ }^{3}$ supaya penyakit tidak kembali lagi.

\subsection{Terapi Alternatif dan Terapi Komplementer}

Menurut National Center for Complementary and Alternative Medicine (NCCAM) ${ }^{4}$ baik terapi alternatif maupun terapi komplementer adalah usaha dari beragam sistem perawatan medis dan kesehatan, praktik, dan produk yang tidak menjadi bagian dari pengobatan konvensional.

Menurut NCCAM, terapi komplementer berbeda dengan terapi alternatif. Terapi komplementer digunakan sebagai pelengkap pengobatan konvensional, misalnya penggunaan aroma terapi bersamaan dengan obat sakit kepala untuk meredakan rasa nyeri. Sedangkan terapi alternatif berperan menggantikan pengobatan konvensional, misalnya melakukan diet khusus untuk mengobati kanker dan bukan dengan menjalani operasi, radiasi, atau kemoterapi yang telah direkomendasikan oleh dokter konvensional.

Menurut The Richard and Hinda Rosenthal Lectures $^{5}$, definisi terapi komplementer dan alternatif (Complementary and Alternative Medicine/CAM) mencakup beberapa pandangan yang luas dari praktik dan keyakinan: 
1. Sebagai praktik yang tidak sesuai dengan standar praktisi medis konvensional.

2. Secara fungsional dapat bersifat saling melengkapi (atau komplementer) akan tetapi tidak diajarkan secara luas di sekolah-sekolah medis pada umumnya.

3. Sebagai terapi "pelengkap" metode konvensional yang memiliki manfaat untuk meningkatkan kesehatan secara menyeluruh, misalnya dengan diversifikasi obat.

4. Sebagai terminologi yang digunakan untuk menampung praktik-praktik terapi yang masih kontroversial. Maka, label yang umum digunakan misalnya, "alternatif", "tidak konvensional", atau "belum terbukti". Label tersebut berpotensi untuk menghakimi sehingga menghambat penyelidikan kolaboratif dan wacana yang diperlukan untuk membedakan terapi mana yang efektif dan bisa dipertanggungjawabkan.

5. Terapi komplementer dan alternatif adalah istilah yang saat ini digunakan oleh Lembaga Kesehatan Nasional Amerika untuk menunjukkan bahwa berbagai terapi ini masih dalam pengkajian dan penyelidikan.

6. Sebagai praktik kesehatan di luar bidang kedokteran konvensional yang belum divalidasi menggunakan metode ilmiah.

Tabel "perbandingan paradigma pengobatan" berikut akan membantu kita dalam memahami dan membandingkan pengobatan konvensional dan alternatif, serta mempelajari asumsi-asumsi yang mendasari teori, praktek, asumsi tentang asal-usul penyakit, makna kesehatan, proses penyembuhan, dan pandangan tentang hidup sehat ${ }^{6}$.

\subsection{Taksonomi Terapi Alternatif Menurut NCCAM}

Sampai sekarang ini menurut NCCAM ada lebih dari lima puluh metode (healing modalities) dalam terapi alternatif ${ }^{7}$ yang dapat dikategorikan menjadi lima kategori, tetapi kadangkala satu jenis terapi bisa mencakup beberapa kategori. Pengelompokan ini mempertimbangkan sumbersumber daya penyembuhan yang digunakan dalam terapi alternatif.

\section{a. Terapi dengan Obat}

Sistem ini disebut juga Alternative Medical System/ Healing System yang terdiri dari terapi Homeopathy, Naturopathy, Ayurveda dan Traditional Chinese Medicine (selanjutnya disingkat TCM). Sistem ini bekerja dari dalam tubuh yaitu pada tingkat molekul dan selsel tubuh untuk membuang sel-sel mati dan meningkatkan produksi sel-sel pelindung baru secara seimbang.

\section{b. Terapi dengan Fokus Pengolahan Pikiran}

Sistem terapi ini disebut juga Mind-Body Intervention yang terdiri dari beberapa metode: Meditasi, Autogeniks, Relaksasi Progresif, Visualisasi Kreatif, Hipnoterapi, Neuro Linguistik Programming (NLP), Brain Gym, Brain Wave Vibration, dan Bach Flower Remedy. Sistem ini bekerja pada gelombang otak untuk mengoptimalkan frekuensi atau getaran yang kita butuhkan agar menjadi semakin sehat.

Tabel Perbandingan Paradigma Pengobatan

\begin{tabular}{|l|l|l|}
\hline \multicolumn{1}{|c|}{ Aspek } & \multicolumn{1}{c|}{ Konvensional } & \multicolumn{1}{c|}{ Alternatif } \\
\hline Tubuh, pikiran, dan jiwa & "terpisah" & "satu keutuhan" \\
\hline Tubuh adalah & ibarat mesin & ibarat mikrokosmos yang hidup \\
\hline Penyakit timbul karena & ada bagian yang rusak & daya kehidupan tidak harmonis \\
\hline Peran obat & melawan penyakit & $\begin{array}{l}\text { memulihkan keharmonisan } \\
\text { tubuh, pikiran, dan jiwa }\end{array}$ \\
\hline Pendekatan & merawat dan mengatasi gejala & mencari pola yang tidak harmonis \\
\hline Fokus & bagian atau fisik & keseluruhan atau energy \\
\hline Perawatan & menyembuhkan bagian yang sakit & $\begin{array}{l}\text { mendorong mencapai } \\
\text { penyembuhan diri sendiri }\end{array}$ \\
\hline Tindakan utama & penggunaan obat, operasi & $\begin{array}{l}\text { diet, latihan, herbal, } \\
\text { managemen stress, dukungan sosial }\end{array}$ \\
\hline Sistem untuk & membebaskan dari sakit & merawat kehidupan \\
\hline
\end{tabular}




\section{c. Terapi dengan Herbal atau Organik}

Sistem terapi ini disebut juga Terapi Biologis yang terdiri dari Terapi Herbal, Terapi Nutrisi, Food Combining, Terapi Jus, Makrobiotik, Terapi Urin, dan Colon Hydrotherapy. Sistem ini hampir sama dengan Alternative Medical System yang bekerja dari dalam tubuh (pencernaan) di mana zat alami yang dimasukkan ke dalam tubuh akan menstimulasi proses pemulihan secara alami.

\section{d. Terapi dengan Metode Gerak dan Sentuhan}

Sistem ini terdiri dari berbagai macam metode pijat atau Massage, Aromatherapy, Hydrotherapy, Pilates, Chiropractic, Yoga, Terapi Craniosacral, dan Teknik Buteyko. Sistem ini menstimulasi pada tingkat jaringan dan otot-otot tubuh. Tubuh yang sehat adalah tanda dan sarana jiwa dan pikiran yang sehat pula.

\section{e. Terapi dengan Pengolahan Frekuensi dan Energi}

Sistem ini terdiri dari Sound healing, Akupunktur, Akupressur, Pijat refleksi, Chi Kung, Tai Chi, Rei-ki, Emotion Freedom Technique (EFT), Theta Healing Science dan Prana atau Pranic healing. Terapi dengan basis ini berfokus pada cara memanfaatkan "energi kehidupan" untuk mewujudkan keseimbangan dan kesehatan. Beberapa metode menggunakan sentuhan tangan, beberapa yang lain dengan metode tanpa sentuhan. Terapi-terapi dengan metode ini selalu melibatkan pemahaman akan aura, medan energi manusia, cakra, dan sistem meridian tubuh.

\subsection{Taksonomi Terapi Alternatif Di Luar Kategori NCCAM}

Klasifikasi yang dibuat NCCAM membantu memetakan model terapi alternatif yang sudah ada. Akan tetapi ternyata ada beberapa metode alternatif yang berada di luar klasifikasi itu seperti Energy Medicine dan terapi-terapi berbasis pengolahan kesadaran seperti: $R e$ connective Healing ${ }^{8}$ yang ditemukan oleh Eric Pearl dan mulai dipopulerkan tahun 2001, Brain Wave Vibration ${ }^{9}$ ditemukan oleh Ilchi Lee dan dipopulerkan tahun 2005, Matrix Energetics $^{10}$ ditemukan oleh Richard Bartlett dan dipopulerkan tahun 2007, Quantum Entrainment $^{11}$ ditemukan Frank Kinslow dan dipopulerkan tahun 2008, Healing Code ${ }^{12}$ ditemukan Alex Loyd yang dipopulerkan tahun 2010 serta Energy Psychology ${ }^{13}$. Masih banyak metode baru lainnya, tetapi yang dipakai di sini adalah metode baru yang buku rujukannya sudah bisa didapatkan di Indonesia.

\section{KEKAYAAN FILOSOFI DALAM BEBERAPA TERAPI ALTERNATIF}

Menarik untuk melihat bahwa meskipun ada beragam metode terapi alternatif seperti Traditional Chinese Medicine (TCM), Akupunktur, Akupressur, Tai Chi, Chi Kung, Chi Nei Tsang, dan berbagai aliran Reiki, mereka memiliki filosofi yang sama yaitu pemahaman akan keseimbangan chi dalam tubuh dan relasinya dengan alam semesta. Dalam tradisi Cina, chi adalah kekuatan hidup yang menyelubungi alam semesta. Selain berada dalam setiap makhluk hidup, chi juga ditemukan di ruang seperti rumah dan lingkungan sekitar. Pemahaman tentang chi tersebar luas di banyak negara Asia dengan berbagai nama.

\subsection{Filosofi $\mathrm{Chi}$}

Konsep chi tidak mudah dipahami secara rasional. Sains belum bisa menjelaskan secara ilmiah. Tetapi tradisi Cina telah ribuan tahun menghayati chi sebagai filosofi kehidupan mereka. Secara sederhana chi adalah energi atau kekuatan hidup. Segala sesuatu yang terjadi di alam semesta melibatkan pergerakan chi dengan berbagai cara.

Paham tentang Chi dalam tradisi Cina sebenarnya adalah salah satu ajaran pokok Taoisme. Chi selalu mengalir dalam dunia. Chi adalah energi yang menjiwai kehidupan. Chi selalu mengalir dan bergetar terus-menerus pada tingkat molekul, atom, dan sub-atom dalam alam semesta ini. Chi, di Jepang disebut "ki" dan di India disebut "phrana" atau "shakti". Orang-orang Yunani kuno menyebutnya sebagai "pneuma".

Pemahaman dasar dalam ilmu pengobatan Cina (akupunktur dan obat herbal) adalah bahwa chi yang seimbang dan mengalir bebas akan menghasilkan kesehatan, sedangkan chi yang tidak seimbang, menumpuk, macet, atau akan menyebabkan penyakit. Hal ini berlaku tidak hanya pada tingkat tubuh manusia, tetapi juga 
bagi lingkungan sekitar manusia. Dengan prinsip seperti inilah seorang ahli akupuntur melakukan diagnosa terhadap ketidakseimbangan energi tubuh, dan bekerja untuk membuka sumbatan dan mengalirkan kembali aliran chi dalam tubuh manusia. Maka dengan membersihkan energi ini kita dapat membuka kembali aliran chi dalam diri kita sehingga terjadilah penyembuhan dalam tubuh, pikiran dan jiwa.

Di dalam tubuh manusia chi mengikuti apa yang disebut "meridian energi" atau "meridian chi" sebagai jalur alami dalam tubuh yang menghubungkan semua organ, sistem, jaringan, molekul, dari makro ke mikroseluler. Meridian ini datang bersama-sama atau fokus di berbagai tempat di dalam tubuh, yang paling terkenal yang terletak di puncak kepala, dahi, tenggorokan, jantung, perut, dantian, dan daerah di tengah selangkangan. Pusat chi dan pusat chakra menempati wilayah yang sama.

\subsection{Lima Unsur Kehidupan}

Para guru Cina kuno mengamati bahwa chi bergerak dalam sebuah siklus yang dinamai “Wu Hsing” (五行, Wu Xing) yang berarti "Lima Tahapan", "Lima Agen", "Lima Unsur", atau "Lima Langkah atau Gerak". Lima Unsur peredaran chi di alam terdiri dari unsur api, bumi, logam, air dan kayu. Kelima elemen menggambarkan karakteristik chi ketika bergerak meresapi musim dan waktu serta menggambarkan bentuknya di alam dan dalam diri manusia.

Dalam filsafat Cina alam semesta terdiri dari langit dan bumi. Lima planet utama berhubungan dengan unsur-unsur: (1) Jupiter (木星) : unsur kayu (木), (2) Mars 火星: unsur api (火), (3) Saturnus (土星) : unsur bumi (土), (4)Venus (金 星 ): unsur logam (金), (5) Mercury 水星: unsur air (水). Bulan diwakili Yin (阴) dan matahari ( 太阳) diwakili Yang (阳). Yin Yang dan kelima unsur menggambarkan sistem kosmologi dan filsafat Cina kuno yang ditemukan dalam kitab I Ching sebagai kitab tertua dari teks-teks klasik Cina.

Dalam filosofi lima unsur kehidupan, masingmasing unsur memiliki musim, organ tertentu, emosi, dan indera yang terkait dengan itu, seperti rasa, bau, dan warna. Unsur kayu, api, bumi, logam, dan air merupakan aspek energi yang saling terkait di seluruh alam, termasuk dalam tubuh manusia.

\subsection{Dantian}

Dalam tubuh manusia, chi secara alami disimpan dalam bagian tubuh yang disebut Dantian. Dantian ${ }^{14}$ adalah konsep yang sering muncul dalam filsafat, pengobatan, dan seni bela diri Cina. Dantian sering dieja sebagai Dan Tien, atau tan t'ien, karena fakta bahwa romanisasi sering tidak begitu utuh mewakili karakter Cina. Dantian adalah pusat gravitasi tubuh, dan dalam teori chi, dantian berperan sebagai pusat penyimpanan energi atau kekuatan hidup. Letaknya tepat di bawah dan di belakang pusar, meskipun beberapa tradisi menunjukkan bahwa tubuh sebenarnya memiliki tiga poin dari Dantian: dahi, jantung, dan pusar.

\subsection{Sistem Meridian}

Meridian merupakan jaringan peredaran chi yang tersebar di dalam tubuh. Jika darah mempunyai jaringan sirkulasi darah, dan syaraf mempunyai jaringan syaraf, maka chi juga mempunyai jaringannya sendiri yaitu meridian. Meridian terdiri dari banyak titik, yang secara normal akan membentuk garis, pada tubuh. Meridian mengalir di dalam tubuh, tetapi tidak dapat dibedah lalu dilihat. Meridian adalah bagian anatomi energi halus tubuh dan tidak memiliki bentuk yang konkret. Manusia dan semua mamalia memiliki meridian.

Meskipun meridian tidak tampak oleh mata, meridian ada karena dampaknya bisa dirasakan. Pelemahan atau penguatan beberapa meridian memiliki dampak yang nyata pada tingkat energi, suasana hati, dan kemampuan adaptasi, kesehatan, kekebalan, berpikir dan kognisi, serta banyak lagi. Meridian tubuh terdiri dari meridian yin dan meridian yang, masing-masing sesuai dengan unsur dan kecenderungan emosional tertentu.

\subsection{Yin Yang}

Konsep berikutnya yang tak bisa dilepaskan dari chi adalah yin - yang. Menurut kosmologi Tao, inilah dua bentuk yang paling mendasar dari chi. Simbol Yin-Yang merupakan pemahaman Cina kuno tentang bagaimana sesuatu bekerja. Lingkaran luar merupakan "segala sesuatu", sedangkan bentuk hitam dan putih dalam lingkaran mewakili interaksi dua energi yang disebut "yin" (hitam) dan "yang" (putih), yang 
menyebabkan segala sesuatu terjadi. Yin-Yang tidak benar-benar hitam atau putih, sama seperti setiap hal dalam hidup tidak sepenuhnya hitam atau putih, dan mereka tidak bisa ada tanpa satu sama lain. Sementara "yin" mewakili keadaan gelap, pasif, bawah, dingin, menyusut, dan lemah, "yang" mewakili keadaan yang cerah, aktif, atas, panas, mengembang, dan kuat.

\subsection{Filosofi Prana}

Metode Yoga dengan berbagai alirannya dan Pranic Healing, ternyata mengolah pusat yang sama yang disebut Prana. Konsep Prana hampir sama dengan chi. Prana adalah istilah sansekerta yang berarti energi vital atau daya hidup yang memberikan kehidupan bagi seluruh alam semesta termasuk kehidupan manusia.

Prana adalah energi atau kekuatan alam semesta. Prana adalah keseluruhan dari semua energi yang terwujud di alam semesta, semua kekuatan di alam dan kekuatan yang tersembunyi dalam tubuh makhluk hidup dan yang berada di sekitar kita. Panas, cahaya, listrik, magnetisme adalah manifestasi dari prana dalam keadaan statis maupun dinamis. Dalam tubuh manusia, Prana bergerak melalui simpul-simpul atau gerbang energi yang disebut Cakra.

\subsection{Cakra}

Cakra adalah konsep imajiner yang dikembangkan para yogis di India untuk menunjukkan bahwa tubuh manusia terdiri dari tujuh pusat energi. Secara jasmani, cakra tidak bisa dilihat. Kalau tubuh manusia dibedah pun kita tidak akan menemukannya sebab cakra terdapat pada tubuh bioplasmik. Cakra berasal dari kata Sansekerta yang berarti lingkaran, pusaran, atau roda yang berputar. Setiap Cakra memiliki warna yang berbeda. Cakra adalah pusat utama dari kekuatan spiritual dan lingkaran energi yang seimbang dalam tubuh manusia. Cakra menyimpan dan mendistribusikan energi dari semua kehidupan melalui tubuh fisik kita sepanjang tubuh energi kita. Tubuh energi adalah eksistensi non fisik atau dikenal sebagai jiwa atau roh yang menempati tubuh fisik kita.

Dalam tubuh manusia ada tujuh cakra primer dan sekitar seratus cakra sekunder yang lebih kecil dan menyebar. Jalinan cakra sekunder inilah yang sering disebut jalur meridian dalam metode akupuntur sebagai jalur aliran Chi. Titik- titik cakra sekunder dipengaruhi oleh tindakan atau gerak tubuh, sedangkan tujuh cakra primer berurusan dengan pikiran, perasaan atau emosi, dan spiritualitas yang amat memengaruhi dan mengatur seluruh fungsi tubuh, metabolisme, sirkulasi, eliminasi, reproduksi. Tujuh cakra primer manusia adalah (1) Cakra Mahkota, (2) Cakra Ajna, (3) Cakra Tenggorokan, (4) Cakra Jantung, (5) Cakra Pusar, (6) Cakra Seks, dan (7) Cakra Dasar.

\subsection{Kundalini}

Membicarakan konsep Prana dan Cakra, mau tak mau membawa kita bersinggungan dengan konsep Kundalini. Kundalini adalah konsep antropologi Hindu untuk menyebut "energi transformatif yang membangkitkan kesadaran diri", "energi yang melingkar", "kumparan" atau "kekuatan seperti ular yang bangun". Kundalini juga telah dikenal selama ribuan tahun di kalangan penganut okultisme, hermetisme, alkemis dan kultus esoteris di Eropa

Apa hubungan antara Cakra dan Kundalini? Ketika kundalini bangkit, ia memberi tahu masalah-masalah pada cakra-cakra tubuh kita. Praktisi yang melakukan meditasi cakra bersama dengan latihan yoga, berusaha agar energi dari Kundalini mengalir secara alami tanpa hambatan. Ketika diaktifkan, energi akan bergerak dari cakra dasar menuju ke atas melalui kolom tulang belakang (sushumna) menuju cakra mahkota. Kemudian energi ini keluar dari tubuh, masuk dalam lapisan aura, menyatu dengan energi alam semesta dan kembali ke tubuh dengan sirkuit energi yang lebih besar. Pengalaman bersatunya energi Kundalini yang personal dengan energi alam semesta inilah yang menghasilkan pencerahan. Aktivasi Kundalini dilakukan dengan metode meditasi cakra, doa, mantera, olah nafas, ataupun yoga.

\subsection{Filosofi "Kesadaran Diri" sebagai Basis Metode Terapi}

Mekanika Kuantum sendiri sudah mulai dikenal sejak Konferensi Kopenhagen tahun 1927 dan orang mulai memahami kekurangan dari mekanika Newton. Akan tetapi, ternyata butuh lebih dari 70 tahun bagi seseorang untuk bereksperimen dan membuktikan kebenaran teori ini kepada publik. Seorang ahli matematika, John von Neumann menyatakan sebuah ungkapan, 
"consciousness collapses the wave," untuk menjelaskan bagaimana sesuatu yang secara fisik tampak solid dapat ditransformasi ke dalam bentuk gelombang dan kemudian mendapatkan bentuknya yang baru (reconfigured). Unsur-unsur kesadaran yang utama digunakan pada metodemetode ini antara lain adalah fokus, intensi, imajinasi, observasi, dan visualisasi.

Fisikawan terkemuka, Dr William A. Tiller dalam percobaannya telah membuktikan bahwa kesadaran manusia mampu "mengubah ruang". Dia menjelaskan bagaimana hal ini bekerja dengan cara yang mudah bagi kita untuk memahaminya dalam How the Power of Intention Alters Matter ${ }^{15}$.

Quantum Entrainment secara spesifik menyebut bahwa dengan pure awareness tubuh akan menemukan cara sendiri untuk beristirahat secara sempurna (deep rest). Dengan cara ini dalam diri kita terjadi pemulihan dan penyembuhan secara fisik, emosional atau spiritual. Matrix Energetics secara berbeda menunjukkan bahwa sintesis energi tubuh dan prinsip-prinsip mekanika kuantum bisa terjadi ketika kesadaran akan sebuah relasi betul-betul diamati dan dirasakan. Metode ini mengajak peserta untuk mengubah kesadaran dengan aplikasi visualisasi dan imajinasi aktif.

Alex Loyd menemukan cara berbeda untuk mengaktifkan satu kunci di dalam tubuh yang secara konsisten akan menghilangkan sumber penyakit dan gejalanya. Cara ini meningkatkan kekebalan tubuh agar melakukan proses penyembuhan secara alami. Inilah proses Healing Codes. Cara aktivasinya adalah dengan kesadaran, pengakuan, dan afirmasi positif. Reconnective Healing adalah bentuk penyembuhan yang menghubungkan kembali kita pada kebaikan dan kemurahan alam semesta. Kita akan dapat menghubungkan diri kita kembali dengan alam semesta dengan mengaktifkan kesadaran akan adanya frekuensi penyembuhan dengan gelombang frekuensi yang sama sekali baru. Dengan proses reconnection ini penyembuhan berlangsung.

Ada sesuatu yang saya amati sebagai bentuk "terobosan" pada metode-metode baru ini. Dalam dunia healing saat ini, banyak teknik baru yang sudah teruji. Metode yang ditemukan semakin sederhana, mudah dipahami, dan mudah diterapkan tanpa suatu persyaratan khusus. Para penemu atau perintis metode-metode baru ini adalah orang-orang profesional yang mau selalu belajar, bekerja keras terus-menerus, dan memiliki keterbukaan juga untuk berbagi metode kepada banyak orang. Bukan berarti bahwa metode yang lama tidak cukup lagi, sebab metode-metode baru ini muncul sebagai sebuah bentuk kemajuan dari metode sebelumnya. Terobosan ini disebut dengan Shift dan Shift of the Ages ${ }^{16}$ oleh Gregg Braden.

\section{PERTANGGUNGJAWABAN RASIONAL ATAS BEBERAPA TERAPI ALTERNATIF}

Sampai saat ini sebagian besar ilmuwan masih menyatakan bahwa usaha-usaha mencapai penyembuhan melalui pengolahan medan energi tubuh manusia adalah sebuah kemustahilan. Kesimpulan ini diambil karena kurangnya pembuktian yang tersedia dan kendala pengujian ilmiahnya. Akan tetapi, perkembangan ilmu pengetahuan tak pernah berhenti sejalan dengan perubahan waktu. Saat ini sudah ada peningkatan jumlah penelitian empiris yang memberikan dasar kuat kepada konsep bahwa fenomena bioenergi tidak hanya ada tetapi juga menjadi pertimbangan utama dalam setiap proses penyembuhan.

Banyak hal yang telah ditemukan dan dipublikasikan tentang sistem energi tubuh selama dua puluh tahun terakhir merupakan hasil kerja studi ilmiah. Pada dasarnya, kemajuankemajuan yang ditemukan dalam bidang disiplin akademis baru yang muncul dengan nama seperti Neuroscience, Neuro Engineering, Energy Psychology, Energy Therapy, dan Energy Medicine mulai menambah pengetahuan kita tentang banyak aspek yang terlibat dalam eksistensi kemanusiaan kita. Kemajuan-kemajuan ini secara khusus berhubungan dengan status energi dalam sistem fisiologis tubuh yang berkontribusi pada keseluruhan kesehatan personal. Energy Medicine dan Energy Psychology mulai membuat terobosan untuk mencapai pemahaman ilmiah dari teka-teki yang dinyatakan Werner Heisenberg beberapa tahun yang lalu:

"Sama seperti dalam kasus Kimia, kita belajar dari pengalaman Biologi sederhana bahwa makhluk hidup menampilkan tingkat stabilitas struktur dasar yang terdiri dari berbagai jenis molekul yang rumit dan tidak bisa hanya mendasarkan pada hukum-hukum Fisika dan Kimia saja. Oleh karena itu, ada 
sesuatu yang harus ditambahkan dalam hukum Fisika dan Kimia sebelum fenomena Biologi dapat sepenuhnya dipahami (1023) ${ }^{17}$ ?.

\subsection{Penjelasan Teori Fisika Listrik}

Dari teori Fisika Listrik ini secara praktis adalah penggunaan magnet dalam mesin pembangkit energi maupun peralatan yang menggunakan sistem kumparan. Hukum Faraday ini memberikan landasan pemahaman bahwa mengubah gerak atau waktu dari medan magnet dalam ruang di sekitar tubuh akan memengaruhi juga aliran arus listrik di dalam tubuh. Karenanya hukum Faraday menjadi dasar untuk terapi berbasis energi baik yang dengan sentuhan (touching) seperti Energy Medicine, Akupunktur, Akupressur, pijat refleksi, Rei-ki, Emotion Freedom Technique (EFT), maupun tanpa sentuhan (non touching) seperti Chi Kung, Tai Chi, Theta Healing Science, Pranic Healing .

Medan listrik atau medan magnet tubuh adalah gelombang arus listrik yang bersifat dinamis, di mana ion, molekul, proses selular, dan jaringan bergerak di seluruh struktur secara integratif sebagai bio-informasi. Gelombang medan listrik tubuh ini bersifat peka terhadap interaksi terapi, dengan metode akustik (misalnya pada sound healing), sensasi, tekanan, variasi suhu, herbal, cahaya, aroma, atau senam atau gerakan yang menyelaraskan getaran.

\subsection{Penjelasan Teori Epigenetika}

Kata "epi" pada Epigenetika berasal dari bahasa Yunani yang berarti "on top of" (di atas, ditumpangi) atau "in addition to" (tambahan pada) genetik. Sedangkan yang dimaksud dengan Epigenetika yaitu ilmu yang mempelajari perubahan dari suatu fenotip (penampakan) yang disebabkan oleh mekanisme yang bukan karena terjadinya perubahan dari genotip (tanpa terjadi perubahan susunan DNA) suatu individu. Perubahan tersebut bahkan bisa bertahan sampai beberapa generasi. Perbedaan mendasar antara kode genetik DNA lama dan Epigenetika adalah bahwa gagasan lama mendukung determinisme genetik dengan keyakinan bahwa gen menakdirkan dan mengontrol fisiologis, perilaku, dan sifat kita.

Menurut Bruce Lipton, kita bukanlah budak gen kita sendiri. Lingkungan memainkan peranan besar dan bagaimana kita mempersepsikan lingkungan kita dapat memberi dampak pada ekspresi gen. Dengan mengubah lingkungan atau persepsi kita akan lingkungan, maka sel akan dapat mengubah ekspresi genetiknya. Bagaimana cara kita memicu ekspresi gen, sehingga kita bukan lagi korban gen kita akan tetapi kita menjadi tuan nasib kita sendiri? Caranya adalah dengan menggunakan kesadaran kita. Terapiterapi alternatif dengan basis kesadaran diri seperti Reconnective Healing, Matrix Energetics, Quantum Entrainment, Now Healing, Healing Codes, Quantum Awareness Healing, Energy Psychology, merasa sangat didukung dengan penjelasan di atas.

Menurut Bruce Lipton, untuk jenis terapi yang lain seperti Prana, Chikung, Reiki, Taichi, EFT, Energy Medicine akan bekerja dalam tingkat selular yaitu memengaruhi aktivitas molekul emosi seperti yang ditemukan oleh Candace Pert ${ }^{18}$. Pert menyatakan bahwa rantai pendek asam amino yang disebut peptida, dan reseptornya, adalah "biokimia yang berhubungan dengan emosi". Peptida ditemukan di otak, di perut, otot, kelenjar, dan semua organ utama.

\subsection{Penjelasan Teori Fisika Quantum}

Menurut Fritjof Capra, sebuah analisis yang cermat dari proses observasi dalam fisika atom telah menunjukkan bahwa partikel subatomik tidak memiliki arti sebagai entitas yang terisolasi dan hanya dapat dipahami sebagai interkoneksi antara bagian percobaan dan pengukuran berikutnya. Teori quantum dengan demikian mengungkapkan kesatuan dasar alam semesta. Ini menunjukkan bahwa kita tidak dapat mengurai dunia ke dalam unit terkecil independen yang ada. Ketika kita memasuki dunia materi, alam tidak sedikitpun menunjukkan keterpisahan "blok bangunan dasar" yang terisolasi, melainkan tampak sebagai jaringan hubungan yang rumit antara berbagai bagian dari keseluruhan ${ }^{19}$.

Beberapa terapi seperti Chi Kung, Tai Chi, Rei-ki, Emotion Freedom Technique, Theta Healing Science, Pranic Healing, Energy Medicine, Accupresure, dan Accupuncture melihat bahwa tubuh manusia secara keseluruhan adalah medan energi. Fisika Quantum juga melihat bahwa tubuh seluruhnya terdiri dari energi. Jika kita terus menyusuri melampaui tingkat atom, kita akhirnya akan menemukan apa yang dikenal sebagai "super string" ${ }^{20}$ yang 
merupakan getaran energi murni. String memiliki tingkat frekuensi yang ketika bergetar akan menentukan jenis materi yang dibentuk. Subpartikel subatomik kemudian berinteraksi satu sama lain dengan cara yang akhirnya membentuk atom. Atom-atom membentuk molekul yang membentuk sel-sel, dan sel-sel pada akhirnya membentuk tubuh kita.

Dalam pemahaman ini, resonansi energi berpengaruh banyak terhadap tubuh kita. Kabar baiknya adalah, bahwa gaya hidup kita seperti sebuah alat musik gesek, kita dapat mengatur string ini untuk memberikan resonansi dan frekuensi yang lebih bermanfaat bagi keberadaan kita. Tetapi, sebaliknya, jika kita tidak memperhatikan energi tubuh kita, kita akan menemukan hal-hal yang tidak selaras dan mengarah pada pengalaman yang tidak menyenangkan. Kegagalan untuk memahami irama dan pola tubuh secara serius menyebabkan banyak orang menderita depresi, kecemasan, stres, dan berbagai penyakit. Jika kita belajar untuk menggunakan "energi" penyembuhan untuk mengolah energi dalam tubuh, kita semakin memahami tingkat kesehatan tubuh yang kita inginkan.

\subsection{Penjelasan Teori Gelombang Otak ${ }^{21}$}

Otak kita terdiri dari milyaran sel otak yang disebut neuron. Setiap neuron saling berkomunikasi dengan memancarkan gelombang listrik. Gelombang listrik yang dikeluarkan oleh neuron dalam otak inilah yang disebut "gelombang otak" atau brainwave.

Pada tahun 1990, psikolog Eugene Peniston, bersama dengan Paul J. Kulkosky, mengejutkan para peserta seminar tahunan Association of Applied Psychophysiology and Biofeedback dengan mengumumkan studinya bahwa meditasi pada gelombang otak Alpha dan Theta meningkatkan kesehatan dan menyembuhkan banyak penyakit, kecanduan alkohol dan obat, dan post-traumatic stress disorder (PTSD) ${ }^{22}$.

Peniston dan Kulkosky melakukan pelatihan biofeedback gelombang otak di klinik Menninger kepada pecandu alkohol kronis di Fort Lyon, rumah sakit Colorado. Pasien mereka secara berangsur-angsur menjadi lebih santai dan berkurang tingkat depresinya, tingkat endorfin mulai stabil, dan perkembangan kepribadian bergeser ke arah yang lebih diinginkan. Mereka juga berhenti minum alkohol dan tiga tahun selanjutnya pun bebas dari kecanduan alkohol. Dalam sebuah penelitian Peniston berikutnya, pelatihan meditasi Alpha-Theta kepada para veteran yang menderita trauma kepanikan, kecemasan, depresi, fobia, dan mimpi buruk berhasil menolong 12 dari 15 pria yang mendapat pelatihan selama sebulan.

Kesimpulan mereka adalah bahwa relaksasi pada gelombang Alpha-Theta seperti yang dilakukan pada terapi Meditasi, Autogenik, Relaksasi Progresif, Visualisasi Kreatif, Hipnoterapi, Neuro Linguistic Programming (NLP), Brain Gym, Brain Wave Vibration, Bach Flower Remedy, mampu mengakses ketenangan yang amat dalam dan pelan-pelan mengubah sistem kimiawi dan jalur saraf otak. Otak dan sistem saraf pusat menyembuhkan dirinya sendiri dan kesadaran yang baru mengalir melalui setiap jalur saraf tubuh dan pikiran.

Bagaimana metode relaksasi yang berupa meditasi ini mampu membuat perubahan di otak, tubuh, pikiran, semangat, dan kehidupan seseorang? Praktisi neurofeedback percaya bahwa melatih bagian tertentu di otak dengan merendahkan frekuensi gelombang otak akan membawa darah beroksigen menuju dendrit (impuls reseptor) di daerah otak yang dirawat. Akibatnya, pengisian oksigen ini secara elektrokimiawi mampu menyembuhkan penyakit atau cedera. Aliran darah yang kaya dengan oksigen meningkat dan mereorganisasi dan menguatkan hubungan saraf yang ada untuk membawa energi yang akan menyembuhkan dan meremajakan sel.

\section{REFLEKSI TEOLOGIS DAN PRINSIP- PRINSIP PENILAIAN ATAS TERAPI ALTERNATIF}

Tanggal 25 Maret 2009, Konferensi Uskupuskup Amerika Serikat melarang praktik reiki oleh orang Katolik maupun oleh lembagalembaga kesehatan dan rumah-rumat $\operatorname{retret}^{23}$. Mengapa? Karena terapi reiki dianggap tidak sesuai dengan iman Kristen maupun ilmu pengetahuan, maka tidak ada tempatnya jika lembaga-lembaga Katolik seperti fasilitasfasilitas kesehatan dan rumah-rumah retret, maupun orang-orang yang mewakili Gereja seperti kapelan, mempromosikan atau mendukung terapi reiki. Pernyataan-pernyataan USCCB terasa terlalu dini datangnya dan menghakimi. Riset ilmu pengetahuan perlahan-lahan berkembang dengan perangkat observasi dan 
pengujian yang memadai dan sepadan untuk menanggapi hal-hal dan realita-realita yang bersifat spiritual seperti reiki. Dahulu hal-hal yang bersifat psikis dan mentalis dianggap paranormal semata, tetapi kini sudah ditemukan caranya untuk meneliti dan mengukurnya. Yang tadinya bersifat paranormal kini menjadi perinormal, karena sudah ditemukan perangkat untuk menguji dan menjelaskannya.

Dengan pemahaman filosofis yang jernih atas terapi alternatif, penjelasan sains dengan dasar empiris kuat, pengalaman kontekstual umat beriman akan terapi alternatif, panorama Kitab Suci tentang peristiwa penyembuhan dan rujukan dokumen Gereja tentang budaya, antroplogi, dan prinsip-prinsip moral, kita akan merefleksikan secara teologis peristiwa dan pengalaman penyembuhan atas terapi alternatif. Refleksi teologis ini berguna untuk memahami terapi alternatif secara jernih dalam terang iman Katolik sehingga kita dapat merumuskan penjelasan dan panduan berupa prinsip-prinsip penilaian atas terapi alternatif secara seimbang, netral, dan bijaksana.

\subsection{Terapi Alternatif sebagai Sarana Membantu Sesama dan Memuliakan Allah}

Beberapa praktisi Reiki yang diwawancarai mengatakan, setelah menjalani doa dan penegasan rohani, mereka merasa terpanggil untuk belajar Reiki sambil mengarahkan pusat sumbernya kepada kehadiran Yesus sendiri. Mereka telah menemukan bahwa cara ini sangat efektif untuk penyembuhan bagi orang lain karena Reiki memiliki sifat positip. Reiki yang masuk ke tubuh manusia tidak menimbulkan efek negatif. Seperti halnya tusuk jarum, Reiki juga menggunakan energi sebagai sarananya agar bekerja memperbaiki sirkulasi tubuh energi supaya kembali berfungsi dengan baik. Dengan perbaikan saluran energi dalam tubuh manusia semakin baik pula kesehatan dan kebugaran tubuh kita. Reiki tidak bertentangan dengan pengobatan medis konvensional. Reiki menganjurkan agar tindakan medis terus dilakukan pasien yang sedang menjalani perawatan kedokteran konvensional.

Maraknya metode penyembuhan Reiki tidak lepas dari penyederhanaan metodenya sehingga mudah dipelajari, juga tidak dibutuhkan pengetahuan mistik tertentu. Reiki bisa dipelajari oleh banyak orang yang sudah dewasa dan tidak dibatasi oleh latar belakang agama atau keyakinan apapun. Di beberapa rumah sakit di Amerika Serikat, Reiki menjadi terapi komplementer untuk mendukung kesehatan pasien

Di dalam iman kita sebaiknya melihat terapi alternatif sebagai sarana untuk memuliakan Allah. Selain itu, metode terapi alternatif sebaiknya dilakukan berdasarkan keyakinan bahwa Allah sendirilah sang penyembuh utama. Allah menginginkan kita bekerjasama denganNya dengan kemampuan terbaik kita (Bdk. Evangelium Vitae No 52).

Allah mengutus kita untuk melakukan eksplorasi dan mempelajari metode yang dibutuhkan untuk proses penyembuhan seseorang. Untuk itu, kita boleh melakukan studi kedokteran dan pelatihan medis atau melakukan riset antar disiplin ilmu dalam bidang penyembuhan, sejauh upaya-upaya itu didasarkan pada penghargaan akan misteri penciptaan, sebagai upaya untuk 'membela dan memupuk hidup, menghormati dan mencintainya' (Bdk. Evangelium Vitae No 42). yang pada akhirnya membawa kita kepada Kristus sendiri. Upaya-upaya ini diharap dapat dimanfaatkan oleh sesama yang lain, demi tujuan kemanusiaan.

Dalam beragam terapi alternatif, energi, cahaya, dan kesadaran dianggap sebagai sumbersumber utama dalam proses kesembuhan. Mendasarkan diri pada Allah, bukan berarti mengabaikan peran dari energi, cahaya, dan kesadaran ini. Karena Allah menciptakan segala sesuatu, maka semua sumber-sumber itu berada di bawah kekuasaanNya, "Maka Allah melihat segala yang dijadikan-Nya itu, sungguh amat baik. (Kej 1:31). Oleh karena itu, realitas apa pun yang kita temukan harus kita arahkan kepada Allah sendiri.

\subsection{Terapi Alternatif sebagai Keterlibatan (Umat Beriman) Membela dan Mencintai Kehidupan}

Kondisi sakit menjadi sebuah penderitaan apabila rasa sakit itu meruntuhkan hidup dan merongrong semangat, inisiatif dan segala aktivitas (bdk. Yoh 5:2-4), tidak jelas penyebabnya, sudah diobati tetapi tidak sembuhsembuh, dan membuat si sakit terus bertanya sampai ia kehilangan harapan "mengapa harus saya yang mengalaminya?"(Bdk. Ayub 42:10). Sakit dan penderitaan bahkan membuat Ayub 
sangat putus asa dan hampir kehilangan imannya (Evangelium Vitae No 31 ).

Sakit, penderitaan, dan kematian adalah sesuatu yang manusiawi. Tak seorangpun luput darinya, Kristuspun mengalaminya: sewaktu ia mengambil langkah melawan penderitaan (Bdk. Mrk 3:1-6) dan dihukum mati sebagai orang pendosa (bdk. Mrk 15:31-32.33.34-38). Pengalaman sakit, penderitaan, dan kematian lebih memungkinkan untuk menghadirkan gambar Allah yang menderita (bdk. Yoh 19:1642; Mrk 15:20-42) daripada menghadirkan gambar Allah pencipta (bdk. Kej 1:1). Perjumpaan dengan orang sakit, mau tidak mau menampilkan gambaran konkrit dari Allah yang menderita. Karena telah mengalami sendiri gelapnya penderitaan dan kematian, Allah dalam diri Yesus Kristus mewahyukan diri-Nya sebagai Allah yang menghendaki pemulihan derita hidup manusia. Ia adalah Allah yang menampung segala kerapuhan, kepatahan, dan keterpecahan manusia. Ia adalah Allah yang mencintai manusia, yang mengangkat manusia dari keadaan level terendahnya. Level terendah adalah situasi manusia yang jatuh dalam dosa.

Yesus Kristus adalah puncak wahyu dan pemenuhan janji Allah ${ }^{24}$. Dia adalah Allah yang menjelma yang mewartakan Kerajaan-Nya. Dia adalah Imanuel, Allah beserta kita (Matius 1:22$23)^{25}$. Allah berjanji bahwa Ia beserta kita. Janji itu terlaksana dalam peristiwa-peritiwa sejarah ${ }^{26}$. Allah menyatakan (mewahyukan) diri-Nya dalam bentuk janji dan dalam sejarah yang ditandai oleh janji ${ }^{27}$. Penjelmaan Allah menjadikan Allah nyata secara manusiawi mengalami sejarah suka duka manusia yang dicipta dan dicintai-Nya. Melalui karya-karya Yesus dihadirkanlah Kerajaan Allah di dunia ini. Dalam puncak pemberian diri-Nya dalam sengsara, wafat, dan kebangkitan-Nya memuncaklah karya keselamatan Allah dalam dunia $^{28}$.

Sebagai umat beriman, kita mengimani Yesus Kristus, Allah yang menjadi manusia itu, menyertai perjumpaan kita dengan mereka yang sakit dan menderita. Dialah gambaran Allah paling nyata terlihat dalam perjumpaan dengan orang sakit. Dia dalam sengsara dan kematianNya, yang kemudian dibangkitkan Bapa adalah puncak karya keselamatan Allah yang memberi harapan bagi kita, bahwa hidup tidak akan pernah dimusnahkan tetapi dipulihkan.

Terapi alternatif dengan dasar iman akan Allah yang menghendaki pemulihan derita hidup manusia, semangat melayani yang tinggi, penghargaan akan martabat kehidupan adalah salah satu contoh langkah konkrit membela kehidupan. Terapi alternatif mewujudnyatakan panggilan itu dalam suatu tindakan moral Kristiani, yakni dengan

"membela dan memupuk hidup, menghormati
dan mencintainya: itulah tugas yang oleh
Allah dipercayakan kepada tiap orang,
dengan memanggilnya sebagai citraNya
yang hidup, untuk ikut melaksanakan,
kedaulatanNya sendiri atas dunia..."
(Evangelium Vitae No 42).

Para terapis atau praktisi terlibat dalam hidup orang sakit: ikut memulihkan keadaan mereka dengan menyapa, mendengarkan keluhan, melatih gerakan fisik tertentu, membuatkan ramuan tertentu, menghibur dan menguatkan semangat agar tidak putus asa dalam hidup. Dalam hal ini, terapi alternatif sejalan dengan Evangelium Vitae yang menyebutkan agar dalam setiap langkah membela kehidupan kita,

"...tidak menyerah kepada rasa putus
asa bila menghadapi mereka yang sakit,
menderita, disingkirkan atau berada di
ambang maut. Melainkan menghadapi
semua situasi itu pandangan itu merasa
ditantang untuk menemukan makna;
dan justru dalam keadaan itu terbuka
untuk menangkap pada wajah tiap orang
undangan untuk perjumpaan, dialog, dan
solidaritas"(Evangelium Vitae No 83).

Pelayanan terapi alternatif adalah bentuk keterlibatan menolong sesama yang menderita. Terlibat berarti ikut ambil bagian. Dalam pandangan Kristiani, 'Moral bersama Allah berarti: berperikemanusiaan dalam solidaritas' ${ }^{29}$. Kehadiran dan keterlibatan terapi alternatif dalam menyembuhkan penyakit dan meningkatkan kesehatan masyarakat adalah wujud iman yang nyata dalam hidup bersama sesama yang berada dalam ambang batas kemampuan manusiawi.

Penderitaan hanya mendapat arti, kalau kita mengambil sikap melawan penderitaan dengan mengambil langkah untuk membela hidup. Melawan penderitaan, hidup hanya mendapat arti jika hidup dibela dengan mengambil langkah konkrit. Finalitas pulihnya penderitaan manusia, bagi kita, tentu terjadi 'nanti', di mana dan pada saat kita berjumpa 'muka dengan muka' dengan Tuhan. Tetapi 'nanti' itu kita antisipasi dengan tindakan-tindakan konkrit saat ini, sebab gema 
pemulihan Allah atas hidup manusia tidak pernah lagi diam.

Kini Ia terus menyeru, maka kita tidak bisa lagi menutup telinga dan kita harus bertindak. Karya pemulihan (penyelamatan) yang diprakarsai Allah membutuhkan tangan dan kaki kita semua agar karya-Nya berlangsung terus-menerus dengan seluruh keterlibatan manusia dalam peristiwa kehidupan. "Teologi modern mengenai eschata memperhatikan dan membahas, bagaimana kita beriman dan bagaimana kita hidup sebagai orang yang menantikan"30. Jawabannya adalah bahwa kita menanti dengan menyongsong kedatangan-Nya. Menanti tidak dengan diam, tetapi bergerak bergegas. Menyongsong adalah tindakan aktif antisipatif untuk kedatangan-Nya.

Melibatkan diri dan mengambil bagian dalam hidup sesama yang menderita berarti mengantisipasi masa depan kita semua yang lebih baik dari saat ini. Inilah iman eskatologis di mana sekarang ini manusia mengantisipasi tindakan Allah dan membangun masa depan ${ }^{31}$. Apa arti janji-janji Allah di tengah-tengah orang sakit dan menderita? Yang bisa diharapkan adalah kesetiaan Tuhan akan janji-janjiNya yang terbukti di masa lampau (Mazmur $105,106,107)^{32}$. Allah itu penolong dalam kesesakan. Kita berharap bahwa Allah yang telah membangkitkan Yesus dari antara orang mati ${ }^{33}$, adalah Allah yang membangkitkan semangat hidup kita semua yang berkehendak baik dalam upaya terapi alternatif untuk membuat hidup orang-orang sakit dan yang tak berdaya menjadi lebih baik kualitas hidupnya.

\subsection{Pertanyaan-Pertanyaan untuk Menilai Terapi Alternatif}

Beberapa poin dan pertanyaan berikut ini bisa dijadikan pedoman bagi para terapis atau pasien dan bisa menjadi sarana untuk menilai adanya "panggilan hati" untuk mempelajari metode penyembuhan atau tidak ${ }^{34}$ :

1) Apakah terapi ini wajar, tidak berlebihan, dan tidak merugikan perkembangan manusia sebagai pribadi? Apakah usaha dan cara yang dilakukan itu mengembangkan manusia sebagai pribadi dan mengembangkan sikap hormat pada hidup manusia (bdk. Evangelium Vitae No 42, SRS No. 34 dan CA No 37)? Apakah metode terapi ini memuliakan Allah dan membawa kita lebih dekat kepada-Nya?
Kita sebaiknya waspada terhadap praktisi yang dengan metode terapinya semakin membanggakan diri sehingga pada akhirnya menuju sebuah kultus individu.

2) Dalam terang iman Katolik, kita perlu mempertanyakan apakah terapi ini akan meningkatkan penghayatan dan pendalaman iman akan Kristus? Apakah ada kualitas kehadiran pribadi Kristus daripada penekanan eksklusif pada kebenaran abstrak dari "energi, cahaya, atau kesadaran" pada metode ini? Apakah iman kita akan semakin berkembang sesuai dengan rumusan iman dalam Gereja Katolik? Jika metode yang kita pelajari memiliki dasar pada Kristus, maka metode ini akan memperkuat relasi kita denganNya, bukan hanya efek kesembuhannya saja. Sekali lagi, kriteria ini, berguna juga untuk menerapkan usaha pengobatan yang lain karena tidak jarang pelayanan pengobatan pun memperlakukan seseorang sebagai obyek, bukan sebagai mitra dalam usaha penyembuhan.

3) Dalam proses discernment kita bertanya apakah terapi ini menjadi batu sandungan di kalangan umat Katolik atau tidak? Beberapa orang mungkin merasa positif dan nyaman, bahkan merasa terpanggil untuk menyelidiki metode-metode penyembuhan, sedangkan sebagian yang lain mungkin merasa berkeberatan karena menemukannya bertentangan dengan iman. Kedua pihak tetap harus dihormati dan dicintai. Bagi yang mendukung, kita berikan pendampingan agar tidak menjauh dan meninggalkan iman, bagi yang tidak mendukung kita berikan pemahaman yang lebih seimbang supaya tidak menjadi kelompok yang kaku.

4) Discernment mengandaikan semacam kedekatan relasi antara kita dengan Allah sendiri. Kita perlu membawa masalah itu dalam doa dan bertanya apakah metode terapi ini selaras dengan kehendak Allah atau tidak. Maka amat penting bagi kita untuk memiliki citra positif tentang Allah (bukan pemarah, penuntut balas, cemburu).

5) Adakah alasan ilmiah yang kuat (dari sains dan teknologi) yang mendukung metode ini? Beberapa teori mungkin hanya didasarkan pada pengalaman yang terbatas. Masih harus ada alasan nyata untuk menunjukkan efektivitasnya. Sains dan teknologi adalah usaha "rasional dan bebas, sadar dan 
sukarela, berkat mana manusia 'bertanggung jawab' terhadap perbuatan-perbuatannya dan tunduk pada penilaian Allah" (Veritatis Splendor No 73).

6) Pertanyaan berikutnya: apakah kita cukup terbuka untuk memahami alam semesta dan misterinya dengan cara baru? Atau kita menolak sesuatu yang baru karena takut berhadapan dengan otoritas resmi?

\subsection{Usulan Prinsip-Prinsip Penilaian atas Terapi Alternatif}

Dengan berpedoman pada dokumen Veritatis Splendor No 72-83 dan beberapa pertanyaan untuk menilai terapi alternatif seperti di atas, kita merumuskan prinsip-prinsip untuk menilai terapi alternatif secara moral Katolik seperti yang akan diuraikan berikut ini.

\section{a. Prinsip "Sumber" Dan "Tujuan" Dalam Terapi Alternatif}

Prinsip ini bisa menjadi pegangan bagi para terapis maupun umat Katolik sebagai klien. Dengan mengenali "Sumber" dan "Tujuan" dalam Terapi Alternatif Gereja harus dengan tegas menolak apabila ada terapi alternatif yang "sumber" kesembuhannya adalah kuasa atau kekuatan gelap (seperti makhluk halus, tuyul, prewangan, arwah orang sakti, jin, dan roh-roh yang berlawanan dengan Roh Kudus). Setiap jenis terapi alternatif yang bersumber dari kuasa yang jahat, secara moral adalah jahat dan tidak dapat dipertanggungjawabkan (Bdk. Mat 7:15, 21-23, Mat 24:24, 1 Kor 6:9-10, Veritatis Splendor No 72, 75, 78, 80, 81,82 Katekismus Gereja Katolik 2116, 2117).

Sebagai prinsip untuk melihat "tujuan" pada terapi alternatif, pertanyaan mendasar yang harus dipegang: apakah terapi itu mengembangkan sikap hormat pada hidup manusia (Bdk. Evangelium Vitae No 42, SRS No. 34 dan CA No 37), semakin mengasihi sesama, dan semakin memuliakan Tuhan. Tujuan atau niat baik tidak pernah dapat mengubah suatu perbuatan yang secara intrinsik buruk menjadi suatu perbuatan yang baik atau dapat dibela sebagai suatu pilihan (Veritatis Splendor No 81). Kita tidak boleh melakukan kejahatan agar yang baik mungkin muncul darinya (Rom 3:8). Maka tidak dibenarkan bagi umat beriman memiliki sikap "asalkan dengan niat baik supaya seseorang bisa sembuh, terapi apa pun itu harus dicoba". Obyek- obyek perbuatan manusia yang secara intrinsik buruk jelas berlawanan dengan kemuliaan Sang Pencipta (Veritatis Splendor No 80). Terapi yang "tidak dapat diarahkan kepada Allah" dan "tidak layak bagi pribadi manusia" (Veritatis Splendor No 82) harus ditolak dengan tegas tanpa kompromi.

\section{b. Prinsip "Kejujuran" Terapis dalam Terapi Alternatif}

Untuk mengenali "sumber dan tujuan" beberapa terapi alternatif ternyata tidak mudah. Usaha untuk mengenali "sumber dan tujuan" adalah post factum yang mengandaikan pasien sudah mencoba berapa terapi alternatif. Beberapa terapis ada yang terbuka menjawab dan menjelaskan "sumber dan tujuan" metode mereka kepada para pasien. Tetapi ada juga yang enggan dan terkesan menyembunyikannya sebab berkaitan dengan teknik dan rahasia yang harus dijaga oleh metode ini. Dalam hal ini, setiap klien atau pasien berhak bertanya terlebih dahulu kepada terapis tentang hal ini. Jika jawaban terapis ternyata tidak meyakinkan, tidak terbuka, terkesan menutupi, atau bahkan menolak, maka pasien berhak juga memutuskan untuk tidak menggunakan terapi itu. Bagi terapis perlu memiliki prinsip "jujur" untuk menjelaskan "sumber dan tujuan" terapi mereka sebab dengan kemajuan teknologi informasi saat ini, para pasien akan dengan mudah mencari informasi dari berbagai sumber untuk memperjuangkan hak mereka dalam mendapatkan kesembuhan.

\section{c. Prinsip Manfaat dan Biaya}

Dengan memperhatikan unsur-unsur intrinsik dalam terapi alternatif, lalu kita harus bertanya apakah buah-buah dari metode terapi alternatif ini? Sabda Yesus, "Jadi dari buahnyalah kamu akan mengenal mereka"(Mat 7:20). Kitab Galatia memberikan penjelasan, "Tetapi buah Roh ialah: kasih, sukacita, damai sejahtera, kesabaran, kemurahan, kebaikan, kesetiaan"(Gal 5:22). Dalam usaha mengenali terapi alternatif, kita bisa mempertanyakan apakah metode ini terbuka dan bisa dipelajari oleh semua orang? Sejauh mana ada keterbukaan dalam metode ini? Terbuka menerima kritik dari pihak lain? Apakah pendukung metode ini terbuka untuk dialog dengan orang-orang yang mempertanyakan atau bahkan dengan orang-orang yang berbeda pandangan? 
Pertanyaan lain adalah apakah para terapis juga terbuka bagi "verifikasi eksternal”? Apakah para terapis bersedia untuk menganjurkan konsultasi dan rujukan kepada otoritas medis yang kompeten? Yesus pun mengutus sepuluh orang kusta untuk memperlihatkan diri kepada imam sesuai dengan hukum Yahudi pada waktu itu.

Terapi Prana, Reiki, Quantum Awareness Healing, Pijat Refleksi, dan Akupunktur termasuk jenis terapi yang banyak mengadakan pelayanan publik secara gratis (Terapi Massal atau Bakti Sosial). Meskipun demikian mereka menegaskan bahwa kehadiran terapi ini tidak untuk menggantikan pengobatan konvensional. Karena sifatnya yang terbuka dan tidak terbatas pada kelompok tertentu banyak orang berminat untuk mendapatkan manfaat dari pelayanan cuma-cuma mereka. Akan tetapi orang tidak begitu berminat untuk belajar Prana, Reiki, Quantum Awareness Healing, dan Akupunktur karena bagi masyarakat kelas bawah dan menengah, biaya kursus terapi ini termasuk mahal. Sementara itu, untuk pelayanan terapi pribadi, Prana, Reiki, Quantum Awareness Healing, dan Akupunktur memasang tarif yang cukup terjangkau bagi masyarakat, bahkan secara sukarela tergantung kemampuan pasien membayar.

\section{d. Prinsip "Kewaspadaan" akan Penerimaan Publik}

Komunitas atau kelompok terapis biasanya terlihat saat ada acara-acara pelayanan publik. Adanya komunitas terapis dalam pelayanan publik menunjukkan bahwa terapi alternatif sudah diterima di masyarakat dan memiliki anggota yang semakin banyak dan mereka telah membangun komitmen bersama untuk membantu orang lain.

Bagi umat beriman, hendaknya tidak menilai terapi alternatif dari unsur penerimaan publik saja. Umat beriman perlu kritis dan waspada sebab apa yang kelihatannya secara publik baik dan mendatangkan manfaat bagi banyak orang belum tentu sesuai dengan iman Katolik karena unsur intrinsiknya mungkin tidak sesuai dengan iman dan moralitas Gereja.

Kita bisa bertanya apakah nilai-nilai Kristiani hadir di setiap awal, pertengahan, dan akhir proses keterlibatan kita dengan teori atau metode terapi ini? Apakah kita sudah mempertimbangkan efek selanjutnya yang akan berlangsung pada diri kita sendiri atau orang lain dengan keterlibatan kita ini? Apakah keterlibatan ini membawa kita semakin menghayati iman dalam Yesus Kristus dan hidup sesuai kaidah Injil? Tentu saja pertanyaan-pertanyaan ini tidak hanya untuk mengevaluasi dan mengeksplorasi metode terapi alternatif. Penilaian dan ekplorasi terhadap metode medis konvensional pun kiranya perlu memakai standar yang sama.

\section{PENUTUP}

Penulis mengajukan usulan mengenai beberapa langkah pastoral dalam hal terapi alternatif. Langkah-langkah pastoral ini merupakan pengejawantahan kepedulian Gereja untuk mewujudkan nilai-nilai Injil, agar karya pelayanannya sungguh dapat menanggapi tantangan-tantangan serta kebutuhan-kebutuhan zaman sekarang secara efektif.

\subsection{Mensosialisasikan Prinsip-Prinsip Penilaian Gereja Atas Terapi Alternatif Bagi Umat Beriman}

Salah satu langkah pastoral untuk menegaskan sikap dan pandangan Gereja dalam hal terapi alternatif adalah dengan mengadakan sosialisasi tentang "prinsip dan penilaian Gereja atas terapi alternatif" yang memaparkan (1) Pertanyaan-pertanyaan untuk menilai terapi alternatif, (2) Prinsip "Sumber" dan "Tujuan" dalam terapi alternatif, (3) Prinsip Kejujuran Terapis, (4) Prinsip "Manfaat, Biaya, dan 'Kewaspadaan' akan Penerimaan Publik' pada terapi alternatif, seperti yang telah dibahas secara rinci dalam bab lima. Sosialisasi bisa diwujudkan dengan mengadakan seminar dan semacamnya untuk menjelaskan pandangan dan sikap Gereja terhadap beberapa terapi alternatif. Selain seminar, sosialisasi bisa dilakukan oleh imam dalam homili, dalam acara pendalaman iman, atau dalam pertemuan lingkungan. Yang diharapkan dari sosialisasi ini adalah agar umat beriman dengan suara hati yang jernih, mampu mengambil sikap kritis terhadap terapi alternatif.

\subsection{Membentuk Komunitas atau Paguyuban Terapi Terpadu}

Tujuan dari pembentukan paguyuban para terapis adalah agar Gereja dapat selalu menyapa, mengikuti, memantau, menilai sekaligus meng- 
akomodasi dan menghargai kehadiran para terapis dengan berbagai latar belakang keahlian mereka dan memberikan peluang bagi mereka untuk mewujudkan iman melalui tindakan membantu dan melayani orang-orang sakit.

Paguyuban ini sebaiknya dibentuk bukan dengan tujuan menggantikan metode kedokteran Barat, tetapi melengkapinya, karena kesadaran bahwa masing-masing metode memiliki keterbatasannya sendiri. Paguyuban ini hendaknya menjadi sarana penyadaran bahwa dalam usahanya mengatasi penyakit, orang sebaiknya tidak hanya mengandalkan satu metode. Untuk penyakit tertentu, sangat diperlukan kombinasi berbagai metode penyembuhan. Gereja bisa memfasilitasi pembentukan paguyuban terapis Katolik semacam itu agar para terapis dapat mengadakan pertemuan berkala di antara mereka. Pertemuan itu bisa menjadi sarana dialog, sharing, dan proses belajar yang terus-menerus. Paguyuban itu bisa menjadi sarana perjumpaan antara metode konvensional dan metode alternatif demi meningkatkan kesehatan umat yang lebih baik.

\subsection{Mempromosikan Pola Hidup Sehat kepada Publik}

Gereja hendaknya mendorong paguyuban terapis Katolik untuk "mempromosikan pola hidup sehat" kepada publik melalui pelayanan kesehatan terpadu, yang menggabungkan pengobatan konvensional dan terapi alternatif, misalnya mengintegrasikan akupunktur dengan pengobatan konvensional. Pelayanan ini sebaiknya bersifat publik dan terbuka bagi masyarakat lintas agama.

\subsection{Mengembangkan Hidup Kerohanian bagi Terapis Katolik}

Agar para terapis Katolik senantiasa mendasarkan hidup mereka pada "tanah yang baru" yaitu Allah yang tak terbatas, yang melampaui ciptaan dan semua energi, mereka perlu mengembangkan hidup rohani, misalnya melalui paguyuban terapis Katolik. Bila hidup rohani mereka berkembang, para terapis dengan metode atau ilmu mereka dapat menghadirkan Yesus di setiap proses penyembuhan. Bila hidup rohani mereka berkembang, para terapis, dalam aktivitas pelayanan penyembuhan, mampu menghayati iman akan Yesus Kristus dan menyembuhkan orang sesuai dengan kaidah Injil. Supaya paguyuban terapis itu tidak bersifat eksklusif, Gereja perlu mengingatkan paguyuban itu agar para terapis bisa meluangkan waktu di tengah kesibukan para terapis memberikan terapi, bahwa mereka pun berhak dan bisa berpartisipasi aktif dalam kegiatan-kegiatan gereja.

\section{Cahyo Christanto}

Staf Pendidik di Novisiat St. Stanislaus, Girisonta, Ungaran, Jawa Tengah; Alumnus Program Magister Teologi Universitas Sanata Dharma:tanto@jesuits.net

\section{CATATAN AKHIR}

Tulisan merupakan olahan dari tesis Magister Theologi: "Refleksi dan Prinsip-prinsip Penilaian Teologis, Pertanggungjawaban Rasional, dan Strategi Pastoral Beberapa Terapi Alternatif", Universitas Sanata Dharma Yogyakarta, 2013.

2 Karen Lee Fontaine - Bill Kaszubski, Absolute Beginner's Guide to Alternative Medicine, 2004, 8.

3 Holistic, selanjutnya ditulis "holistik" yaitu suatu pandangan bahwa semua dalam sistem alam semesta ini (fisika, biologi, kimia, sosial, ekonomi, mental, bahasa,psikologi, dll) tidak bisa ditentukan atau dijelaskan secara terpisah saja, tetapi dijelaskan secara menyeluruh.

4 Amy L. Sutton (Ed.), Complementary and Alternative Medicine Sourcebook, Peter E. Ruffner Publisher, Detroit, 2010,3-6.

5 The Richard and Hinda Rosenthal Lectures, Exploring Complementary dan Alternatives Medicine, Institute of Medicine National Academies, The National Academies Press, Washington, D.C., 2001, 1-2.

6 Karen Lee Fontaine - Bill Kaszubski, Absolute Beginner's Guide to Alternative Medicine, 2004, 9.

7 Amy L. Sutton (Ed.), Complementary and Alternative Medicine Sourcebook, 2010, 4.

8 Sudah ada bukunya dalam bahasa Indonesia, The Reconnection, Menyembuhkan Orang Lain, Menyembuhkan Diri Anda Sendiri, Gramedia, Jakarta, 2008.

9 Bisa dilihat di http://www.brainwavevibration.com/. (24 Maret 2012).

10 Metodenya bisa dipelajari dari buku karya Richard Bartlett, Matrix Energetics, The Science and Art of Transformation: A Hands-on to Subtle Energy and Radical Change, Beyond Words, New York, 2007.

11 Metodenya bisa dipelajari dari buku karya Frank J. Kinslow, The Secret of Instant Healing, Lucid Sea, Florida, 2008.

12 Metodenya bisa dipelajari di buku karya Alexander Loyd, The Healing Code: 6 minutes to Heal the Source 
of Your Health, Success, or Relationship Issue, Grand Central Life \& Style, New York, 2010.

13 Bisa dibaca di Neill, N. (2010). What is energy healing psychology? Dari http://www.neillneill.com/132/whatis-energy-healing-psychology/. (24 Maret 2012).

14 Dantian ibarat gerbang energi dalam tubuh kita. Lih. "Membuka Gerbang, Memburu Angin" dalam Mantak dan Maneewan Chia dalam Chi Nei Tsang: Buku Pedoman untuk Kebugaran, Pustaka Delaprasta, Jakarta, 1990,154-175.

15 Dr. William Tiller mengatakan bahwa, "Since every application of our intention is an act of creation, it ultimately teaches us how to create properly, efficiently, and effectively. This turn ultimately manifests I some type or types of events in our sensory world. ", http://www.spiritofmaat.com/archive/mar2/tiller.htm. (24 Maret 2012).

16 Diakses dari: http://www.greggbraden.com/press-andmedia/shifting-to-a-better-world. (24 Maret 2012).

17 Heisenberg on Nature and Science, dari http://realphysics.blogspot.com/2011/01/heisenberg-on-nature-and-science.html. (30 Maret 2012).

18 Candace Pert adalah seorang farmakolog dan pengarang buku Molecules of Emotion: The Scientific Basis Behind Mind-Body Medicine (Scribner, New York, 1997), Everything You Need to Know to Feel Go(o)d (Hay House, California, 2006), dan The Musical Guided Imagery CD Psychosomatic Wellness: Healing your Body-Mind.

19 Fritjof Capra, The Tao of Physics, On Quantum Theory dari http://www.spaceandmotion.com/ Physics-Quantum-Theory-Mechanics.htm.

$(30$ Maret 2012).

20 Teori string muncul sebagai salah satu usaha untuk menggabungkan teori kuantum dan relativitas. Teori ini lahir tahun 1980-an dan terus berkembang hingga sekarang. Awalnya string itu hanya dipandang sebagai objek matematis satu dimensi. Dinaikkan satu dimensi dari titik. Titik itu nol dimensi. Dulu orang mengira kalau penyusun dasar alam semesta adalah objek berbentuk titik, makanya ada istilah partikel dan atom. Wajar karena titik berdimensi nol. Satu dimensi di atas ketiadaan (-1). Tapi karena pusing, para ilmuan mencoba menaikkan saja dimensinya, yaitu menjadi 1 (garis). Bukannya tambah sederhana, malah semakin runyam. Sekarang, gagasan ini sudah mencakup sebelas dimensi. Karena besarnya dimensi yang dimakannya, maka teori ini disebut teori superstring.

21 Sumber: Menguasai Gelombang Otak, Anna Wise, diterjemahkan dari The High Performance Mind oleh Claudia Syanny Latif, PT Gramedia, Jakarta, 2012,1-30.

22 Meditation and Healing. Diakses dari http://www.brainwavetraining.com/meditation healing.htm. (30 Maret 2012).

23 Silakan dilihat di The Reiki Racket, U.S. Bishops Urge Catholics to Avoid New Age 'Therapy' by Jeff Ziegler, http://www.staycatholic.com/reiki.htm

24 Konstitusi Dogmatis tentang Wahyu Ilahi No 4.

25 Tom Jacobs, Imanuel: Perubahan dalam Perumusan Iman akan Yesus Kristus, Kanisius, Yogyakarta, 2000, 15 .
26 Lih. Pandangan eskatologi Moltmann sebagaimana dipaparkan T. Jacobs - B. Kieser dalam "Teologi Modern tentang Eschata", dalam: Diktat mata kuliah Teologi Harapan, 103.

27 Jürgen Moltmann, Theology of Hope, London: SCM PRESS LTD, 1967.

28 Dalam bahasa Moltmann, Allah yang bersimpati pada manusia adalah Yesus Kristus.

29 Bernhard Kieser, SJ, Wahyu Ilahi dalam Penerusan Manusiawi, Diktat kuliah Iman dan Wahyu, Yogyakarta: Fakultas Teologi Sanata Dharma, 2006, 46.

30 T. Jacobs - B. Kieser dalam "Teologi Modern tentang Eschata", dalam: diktat mata kuliah Teologi Harapan, 117.

31 T. Jacobs - B. Kieser dalam "Teologi Modern tentang Eschata", 103.

32 Nico Syukur Dister, Teologi Sistematika II, Kanisius, Yogyakarta, 2004, 507.

33 Nico Syukur Dister, Teologi Sistematika II, Kanisius, Yogyakarta, 2004, 512.

34 Beberapa penyesuaian dari artikel karya Doug Schoeninger-Fabricant Sheila tentang "Metode Evaluasi atas Teori-teori Penyembuhan", Journal of Christian Healing, Vol. 9, No. 1/Spring 1987.

\section{DAFTAR PUSTAKA}

Agness, Lindsey 2010. The True Magic of Neuro Linguistic Programming (terj. Helmy), Garai Ilmu, Yogyakarta.

Bartlett, Richard 2007. Matrix Energetics, The Science and Art of Transformation, Beyond Words Publishing, Oregon.

Carlson, R. - B. Shield, 1989. Healers on Healing, J. Tarcher, Los Angeles.

Chaturvedi, V. S., 2002. All You Wanted to Know about Ayurveda and Chronic Diseases, Sterling Publishers, New Delhi.

Chia,Mantak - M.Chia, 1990. Chi Nei Tsang: Buku Pedoman untuk Kebugaran (terj. T. Zaini Dahlan), Pustaka Delaprasta, Jakarta.

D’Angelo, James 2000. Healing with the Voice: Creating Harmony through the Power of Sound, Thorsons, London.

Dister, Nico Syukur, 2004. Teologi Sistematika II, Ekonomi Keselamatan, Kanisius, Yogyakarta.

Fontaine, K. L. - B. Kaszubski, 2004 Absolute Beginner's Guide to Alternative Medicine, Sam Publishing, Indianapolis. 
Haight, Roger , 1990. Dynamics of Theology, New York.

Hardiman, Budi, F., 2004. Sejarah Filsafat Modern: Dari Machiavelli sampai Nietzsche, Gramedia, Jakarta.

--------------------, 2009. Melampaui Positivisme dan Modernitas: Diskursus Filosofis tentang Metode Ilmiah dan Problem Modernitas, Kanisius, Yogyakarta.

Hay, Louise, 1997. You Can Heal Your Life (terj. I. Sutikno, Pr), Gramedia, Jakarta.

Jacobs, Tom 2000. Imanuel: Perubahan dalam Perumusan Iman akan Yesus Kristus, Kanisius, Yogyakarta.
Kinslow, F. J., 2008. The Secret of Instant Healing, Lucid Sea Publishing, Florida. , 2010. The Secret of Quantum Living, Lucid Sea Publishing, Florida.

Kok, Sui, C., 1990. The Ancient Science and Art of Pranic Healing: Practical Manual on Paranormal Healing, Institute for Inner Studies, Inc., Metro Manila.

Küng, H., 1994. Great Christian thinkers, Continuum, London.

Lee, Ilchi, 2006. Pernapasan Otak (terj. Meitasari Tjandrasa), Buana Ilmu Populer, Jakarta.

Lipton, Bruce, H., 2005. The Biology of Belief: Unleashing the Power of Consciousness, Matter and Miracles, Mountain of Love Santa Rosa, California. 